\title{
Foreword to the Updated and Revised Edition
}

On Tomb-Sweeping Day 2012, a press briefing was held at the Memorial Hall of the Victims of the Nanjing Massacre by Japanese Invaders for the publication of the updated and revised edition of The Rape of Nanking: A Historical Study (Volumes one and two). It is Tomb-Sweeping Day again today, and the first one since the seventh session of the Standing Committee of the $12^{\text {th }}$ National People's Congress of China declared December 13 of each year "National Memorial Day for Nanjing Massacre Victims.”

Solemn ceremonies held on the memorial day have seared the historical event into memory, and this is not just memory of the residents of Nanjing, or the Chinese people, but a collective memory of war and peace belonging to humanity as a whole. There are too many lessons we must learn before all of humanity can unite in a community of shared destiny bound by fraternity and love. The national memorial is a government-organized open-to-the-public ceremony infused with many layers of symbolic significance universally recognized among the Chinese people. The involvement of modern media makes it possible for the peoples of Nanjing, across China, and indeed around the world, to partake in one shared understanding and experience all at the same time.

The national memorial ceremonies are held only on the designated day every year. After several expansions, The Memorial Hall of the Victims of the Nanjing Massacre by Japanese Invaders now provides a public space reserved solely for this purpose. Since the space was finished, it has been able to facilitate personal accounts and expressions. When visitors from around the world enter the space and subjectively experience its concepts, they form an interaction with the words of the space, giving them a panoramic feeling and entry into the experience of the Rape of Nanking.

One could say that the National Memorial Day for the Victims of the Nanjing Massacre and its setting have become a political, social, and emotional force that is impossible to resist; its influence goes without saying.

At the same time, great progress has been made over the past three years in the academic study of the history of the Rape of Nanking. Professor Zhang Xianwen led us in completing Nanjing da tusha quan shi [Complete History of the Rape of Nanking]. Nanjing da tusha yanjiu: lishi yu yanshuo [Research of the Rape of Nanking: History and Discourse], edited by Professors Zhang Lianhong and Sun Zhaiwei, compiled many new achievements by outstanding researchers. Professor Jiang Liangqin and I have issued a series of dedicated papers on the topic in the periodical Lishi yanjiu [Historical Research]. We should note that 
Li Yongdong, Li Hongtao, and others are also exploring new routes to deepen study of the Rape of Nanking.

In recent years, the once boisterous Japanese right wing has fallen into a sullen silence, and produced little by way of influential "achievements". Meanwhile, since a consensus has emerged among scholars around the world that the Rape of Nanking was a historical fact, it is no longer as contentious an issue as it had been. In my opinion, however, this is a sign that the history of the Rape of Nanking has become a serious field of study. Now, in this moment of silence on the eve of a breakthrough, the publication of a revised edition of the two-volume The Rape of Nanking: A Historical Study is both timely and necessary.

In light of this, I would like to continue forward following the in the academic footsteps of Henri Lefebvre, Pierre Bourdieu, Martin Heidegger, and modern scientists. In my view, the history of the Rape of Nanking is different from other periods in China's history. Its overwhelmingly gargantuan influence on the people of China and its prominent position in the domestic and foreign discourses on modern Chinese history give it a massive "gravitational field," slowing down the time of events within its pull. Time and setting are merged into one within the event, or in other words time has become an organic component of its setting. A view of the history of the Rape of Nanking "cut into slices" and "cut into chunks" using accurate timing standards clearly views the scale and intensity of all aspects of the "gravitational field" as unified, whether viewed in parts or all together.

The existence of history is the foundation of study in the field of history. In the study of history, storytelling at the macro scale and tidying up at the micro level are common occurrences, but both are bounded by specific contexts. In the study of the history of the Rape of Nanking, however, both the macro and micro levels transcend "convention."

At the macro level, it is as though the greatest international event could be made to appear on the screen through a "wormhole" as theorized by modern physics: the judgments and attitudes on conditions in the Far East of U.S. President Roosevelt and his Secretary of State Cordell Hull; competition between the army and navy of Japan as well as the whole nation's "explosion" onto the world scene via the World War; Hitler's cold-blooded, "rational" decision between China and Japan; the supernormal indifference and reverse admonishments of the British Empire toward the violence in Nanjing - calling upon Western missionaries to cease collecting evidence of crimes committed by Japanese soldiers - "that is of no use"; Pravda's reproach of the Japanese army's violence and the rising silhouette of Stalin behind China's War of Resistance; Mussolini's picking 
sides despite declared neutrality - nobody was truly unaware of the Rape of Nanking during that time of world "policing."

At the micro level, time in historical studies is usually broken down into years, months, and days, but in this event, we have the early morning, the late morning, noon, afternoon, evening, and night, even down to hours and minutes. The result of the minute breakdown has been the "slowing down of time." As John Rabe put it, "The people feel they are afflicted with a major disease, watching the time tick away with a gaze of terror. Time is passing too slowly, as though there were 100 hours in every day and not 24." Minnie Vautrin concluded that "time seemed to have stopped." This "slowing" of time gives us conditions to observe the unlimited number of historical details and open up multiple "windows" through which to observe the event, and engrave the characteristics that the gift of time has allowed us to see deep in our memories.

December 19, 1937 was possibly a "normal" day during the Rape of Nanking. The reason we cite it as an example here is that special reporter Moriyama of the Tokyo Asahi Shimbun wrote in a cable from Nanjing that day:

In the residential district, boys and girls climbed on broken horse carts, singing and dancing... tranquil eulogies issued forth from the church. This is Pastor John Magee leading his now calmed Chinese congregation in the climax of prayers after the smoke of gunpowder had cleared. Today is Sunday... Today in the square within the Japanese embassy compound, Japanese soldiers are issuing refreshments and rice cakes to refugees, as well as cow's milk and cans for the mothers of infants. It is the living image of good will.

The potential truth of "innovative" reports lies in the question of for whom they are intended. The Japanese reporter clearly stated that this was a Sunday, but the only surgeon left in Nanjing at the time - Dr. Wilson of the Gulou [Kulou] Hospital - wrote in his diary: "I guess it's Sunday." He daily performed several operations for victims and was exhausted to the point of delirium. On this morning, he went with other foreigners to lodge protests at the Japanese embassy, where he met with a secretary named Tanaka: "He himself is sympathetic but has no control over the military." On his way home, Wilson discovered Japanese soldiers looting the home of his friend Daniels, whom he drove off. "This afternoon I took out the third eye I have operated on lately and did five other smaller operations." At dinner time, "the Brady's cook and Mr. Chu... had come in to get someone to go over there and interfere with the raping of all their women." He goes on to say that several blocks near "Tai Ping Road" had been set ablaze. He also reports that a Japanese soldier had undressed himself and gotten in bed with nurses of his hospital.

On that same day, a great number of panic-stricken women and girls flooded into the refugee camp in Ginling Women's College. Vautrin's diary records the 
events down to the hour: "At 8 o'clock a Japanese came in with Mr. Teso from the Embassy. Having been told we had not enough rice for the refugees, I asked him to take me over to headquarters of Safety Zone; this he did, and from there a German car took me over to see Mr. Sone, who has charge of rice distribution. He promised to get us rice by nine o'clock. Later I had to go back with the car to Ninghai Road, the presence of a foreigner is now the only protection for a car. Walking back to college, again and again mothers and fathers and brothers implored me to take their daughters back to Ginling... Later the morning was spent going from one end of the campus to the other trying to get one group of soldiers after another out... in room 538, I found one standing at the door, and one inside already raping a poor girl." That afternoon Vautrin told Japanese officers what had happened. That night, four Japanese "gendarmes" stood guard on the campus. Also that night, she saw the outbreak of at least three major fires in the city.

Time gradually merges with the incident. A picture of the Rape of Nanking clearly emerges with each time sequence, each scene, each perspective, with the chunks of history combining like pieces of a puzzle. The following bit of history drawn from the Safety Zone documents from December 19, 1937 is precise down to the minute:

8:30 a.m., Li Wenyuan, driver for American missionary George Fitch, has had his home looted by Japanese soldiers. All eight members of his family were living in the house of a German at number 16 Luojia Road, with a Nazi swastika flag hanging outside. It was looted anyway of seven chests of clothes, two baskets of household implements, six down blankets, three mosquito nets, rice bowls, and 50 yuan in cash, and the household is now reduced to pennilessness.

3:00 p.m., Japanese soldiers break into the Gulou Hospital. When McCallum and Trimmer ordered them to leave, they opened fire, but thankfully missed.

3:30 p.m., some drunk Japanese soldiers broke into the residence of Red Swastika Society (note: a private charitable organization in China at the time) chairman Tao Xisan (note: later chairman of the puppet Nanjing Autonomous Committee), located at Number 2 Mogan Road. They broke open his chests. Smythe and Sperling prevented "this likely premeditated looting."

4:45 p.m., Miner Searle Bates was called to number 16 Cangping Road, where the Japanese had looted and set fire to the building, which was completely destroyed.

5 p.m., a young man was sent to the Safety Zone headquarters; he had been stabbed in the chest by a Japanese soldier for no reason at all. Fitch and Smythe went to the Japanese embassy to report the violence of the Japanese soldiers and brought the young man to Gulou Hospital.

6 p.m., six Japanese soldiers climbed into the residence of John Rabe in darkness. When Rabe shined his flashlight on one of them, he pointed his pistol at Rabe, who then ordered 
the six to climb back out the way they'd come in. They asked that Rabe let them out by the front door, but "Rabe refused to give them this face."

6 p.m., an employee in the Security Zone came to summon Bates, Fitch, and Smythe to the house at number 19 Hakou Road to drive off four Japanese soldiers presently raping a woman. After they'd been driven off, the woman and her child(ren) were transferred to the main building of University of Nanking.

Incidents at every point in time all encompass a great deal of information and are worthy of detailed dissection and analysis by researchers (who already possess a great deal of "present" knowledge, understanding, and information about the Rape of Nanking and have been molded by such). The "materialization" of time within the Rape of Nanking along with granular and concrete understanding of events therein allow us to feel and experience the Rape of Nanking today several decades hence, just as though we were there; there is still "historical warmth." We can feel the "presence" of the Japanese soldiers at the scenes of each of their crimes, with the "bestial machinery" as described by a German there at the time coming out "in living color." The throngs of Japanese soldiers deliberately committing crimes under orders have been described by Hannah Arendt as "the banality of evil," but in fact their innovative means used in their crimes as well as their breaking through the base lines of humanity were long ago revealed to have been "creative" expressions of far-reaching "evil imagination." The lives of the victimized Chinese were being trampled and stamped out minute by minute, turning time into an "accomplice" of the violence - after 1949, when the Rape of Nanking had long been forgotten, time became another kind of "violence." The neutral Westerners were eyewitnesses to, recorders of, and participators in the "complex of time and events"; today they have come to be guiding emissaries into the events of the Rape of Nanking that stride across history and reality. The history of the Rape of Nanking has its own research concepts and scopes, as well as its own value judgments, and even the routes upon which it relies have their own "norms"; this is precisely the manifestation of its integration with time entities and its reaching of a "higher" plane.

Time has already "begun," and space has already "awoken." Study of the history of the Rape of Nanking within the non-Euclidean space-time complex cannot continue along a "level and smooth track", this means that the demands on us have grown even greater.

The work behind this revision was herculean, with the additions and enrichments of the text going without saying. The redoing of annotations was especially troublesome, adding a great deal of citations of originals in foreign languages to allow those interested in the material to research more on their own. Although I must in advance note that this will sound like a disclaimer, in truth the revised 
edition still fell far short of encompassing all the new thoughts of the authors, despite the amount of work that went into it. I was also unable to open up the broad world that other researchers might have with their more profound studies and wisdom. So please understand that this is merely one achievement along the road of work in progress, for which I earnestly request comments and critiques.

Zhang Sheng

Tomb-Sweeping Day 2015 